\title{
Perceived Effect of Home Grown Feeding Programme on Pupil's Academic Performance in Ogun State, Nigeria: Nexus for Pupils Academic Excellence
}

\author{
${ }^{1}$ Gbenga-Adeaga, Olubunmi Veronica, ${ }^{2}$ Adeoye, Adekunle Stephen. and Awe, Isaac Ademola \\ 1.Department of Mathematics, School of Science, Federal College of Education, Abeokuta \\ 2.Department of Agricultural Extension and Rural Development, Federal University of Agriculture, Abeokuta. \\ P.M.B 2240. Abeokuta. Ogun State, Nigeria
}

\begin{abstract}
This study was conducted to assess the perceived effect of home grown school feeding programme (HGSFP) on pupil's academic performance in Ogun State, Nigeria. The objective of this study was to describe the demographic characteristics of the respondents; influence of HGSFP on pupils' enrollment before and after the commencement of the programme; effect of home-grown feeding program on pupils' academic performance and challenges of HGSFP in the study area. Descriptive survey design was used for this study. A questionnaire was administered to capture the perceived effect HGSFP on 780 respondents (pupils) in four purposively selected Local Government Area of Abeokuta Metropolis. Findings reveals that above half (51.3\%) of the pupils were males, $43.6 \%$ were between the age 4-6years, 33.3\% were 7-9years. The result showed that the pupils had a mean height of $129.72 \pm 11.43$, weight of $24.32 \pm 5.41$, weight for age of $1.76 \pm 1.83$, height for age of $2.93 \pm 2.84$ and BMI for age of $0.074 \pm 1.25$. The anthropometric status of the pupils reveals that majority $(94.9 \%)$ has normal weight-for-age, $4.5 \%$ were underweight and $0.6 \%$ has severe underweight, while majority ( $96.2 \%)$ of the pupils also has normal heightfor age. All (100.0\%) of the teacher indicated that the meals served are assorted and nutritious such as yam, cocoyam porridge, rice, beans, yam porridge, bread, vegetables, eggs, beef, fruits and so on, while majority $(92.9 \%)$ of the teacher indicated that there is an increase in school enrolment due to the provision of HGSFP and $85.7 \%$ of them reveals that the HGSFP is funded through cost sharing between the state and local governments. Challenges in the HGSFP were overcrowded classroom, inadequate storage facility, lack of effective monitoring and evaluation system, insufficient funding and seasonality in the study area. The study concludes that HGSFP was a very good initiative by the government as it enhances pupils' enrollment, attendance, retention dropout, class participation, quality, and cognitive development. It is therefore recommended that ministry of education and the state should review the home grown school feeding program, make it continuous and extend it in schools in poverty ridden areas.
\end{abstract}

Keywords: Perceived Effect; Feeding Programme; Academic; Pupils; Performance; Ogun State.

DOI: $10.7176 / \mathrm{JESD} / 12-22-01$

Publication date: November $30^{\text {th }} 2021$

\section{INTRODUCTION}

Home grown Feeding Programme (HGFP) is a key element in the person's body growth and enhance cognitive development of pupils. Children need a reliable food supply to meet the metabolic supplies of body growth and brain development as noted by (Akanbi, 2013). According to Lawson (2012) who stated that setting priority to school feeding programme is fundamental involvement in reducing the short- term hunger, providing learner's cognitive function by and enhancing the learning environment. The school feeding programme would enable students to increase their regular attendance in school in order to improve their academic performance in all area of school curriculum. The study carried in Abeokuta metropolis had been indicated that the feeding programme had great effect on learner's enrollment and attendance. It is seen that within short term of hunger in the classroom can resulted into low academic performance and many of the children did not have adequate diet while coming to classroom. School feeding programme (SFP) according to World Bank is a targeted social safety nets that provide both educational and health benefits to the most vulnerable children, thereby increasing enrollment and attendance rates, reducing absenteeism, increasing cognitive development and improving food security at the household level (World Food Programme, 2015). Normally, the objectives for the school meals are mainly three as noted by Aliyar, Gelli, and Hamdani(2015) and Bashir, Lockheed, Ninanand Tan, (2018) that school feeding as a social safety net; as a requirement to advance learning and educational outcomes; and to boost nutrition and or health status of the school children.

Home Grown School Feeding Programme (HGSFP) could be seen as a vehicle to stimulate local economies of people by providing a market and source of income for local smallholder farmers (Gelli, Masset, Folso, Kusi, Arhinful, Asante, et al., 2016; Bundy, de Silva, Horton, Jamison and Patton, 2018a). Also, it can be used as a strategy to ensure that School feeding menus contain a variety of nutritious food that school children are accustomed to (Aliyar, Gelliand Hamdani, 2015; Bundy, de Silva, Horton, Jamison and Patton 2018b). Besides, 
the school feeding programme (SFPs) is intended to alleviate short-term hunger, improve nutrition and cognition of children and transfer income to families (Cole, 2013). The causes of poor enrollment, high dropout rates in schools and low academic performance could be as a result of hunger, illness, frequent truancy, lack of school requirements, parent socio-economic status, laziness and among others causes. In developing countries, nearly 60 million children go to school hungry every day and about 40 percentof them are from Africa. Providing school meals is therefore vital in nourishing children. Parents are motivated tosend their children to school instead of keeping them at home to work or care for siblings (Akanbi, 2013).

Nigeria happened to be one of twelve (12) pilot countries invited to implement the programme from the onset. So far, Nigeria, Cote d'ivore, Ghana, Kenya and Mali commenced the implementation of the school feeding programme. As a result, the Federal Government came up with the Universal Basic Education Act in 2004, which provided the enabling legislative backing for the execution of the Home Grown School Feeding and Health Programme. Towards the realization of the objectives of the Universal Basic Education programme and the central role of nutrition, the Federal Ministry of Education launched the Home Grown School Feeding and Health Programme in 2005. The overall goal of the School Feeding Programme in Nigeria is to reduce hunger and malnutrition among school children and enhance the achievement of Universal Basic Education. Ogun State was among the twelve (12) States selected to begin a phased-pilot roll out implementation of the programme. In Ogun State the programme was launched by the Ibikunle Amosun administration on January 30, 2017, simultaneously in 874 schools in Ogun after eight months of preparation. A total of 2,968 women were enrolled and trained as food vendors, with 1,381 of them in the first phase. They were expected to cater to 1,564 primary schools. Several items were distributed to them, including white aprons, white caps, Adire gowns, industrial coal pot, medium warmer $(55 \mathrm{cl})$, small warmer $(30 \mathrm{cl})$, big cooking spoons, long turning sticks, 100 litres drums, iron pails, iron pots, aluminium water basins, water bowls, aluminium sieves, kitchen knives, amongst others.

Poor nutrition and poor health condition among children contribute to the inefficiency of the educational system. Nutrition is an important factor related to child's learning, well-being, performance and productivity. A child who is not properly fed or lacks certain nutrients in his/her diet may not have the same potential for learning, have difficulty in performing complex tasks, and may have critical health conditions that can delay his/her enrolment in school or cause irregular attendance in school. A nation with malnourished citizens suffers setbacks in the areas of human productivity and economic development. Some studies have argued that SFP can increase enrolment, attendance rates as well as test scores among pupils (Ahmed, 2004; Mohamed, 2015; Nyarko, 2014). Furthermore, the nutritional value of the school meal impacts the health status of school pupils positively (Adelman et al., 2008; Gelli et al., 2016). The positive impact associated with SFP has made most of the African nations to introduce the programme in most of their primary schools. The World Food Programme (WFP) estimated that in 2013 there were 30 million children receiving school meals in Sub-Saharan Africa (WFP, 2013). The Home-grown school feeding programme has been impactful in many parts of the study area in Ogun State, Nigeria. There has been high level of awareness of home-grown school feeding programme across the study area due to the effort of the former State Government. There has been great influence of the home-grown school feeding programme through rate of enrolment in most school in the area selected. The school feeding programme in the state had increased enrolment and reduced absenteeism. Since the commencement of the programme rate of pupil's absenteeism has reduced drastically and great improvement is being achieved on pupil's attendance in all the selected area for the study. This study was therefore initiated to investigate the perceived effect of home grown feeding programme on pupil's academic performance in Ogun State, Nigeria: a nexus for academic excellence

\section{Research question}

a) What are the demographic characteristics of the respondents in the study area?

b) What are the influences of home-grown feeding program on pupils' enrolment before and after the commencement of the program?

c) What are the effects of home-grown feeding program on pupils' academic performance in the study area?

d) What are the Challenges of the School Feeding Programme?

\section{Basically, this paper seeks to assess the followingspecific objectives for the study}

1. describe are the demographic characteristics of the respondents in the study area.

2. examine the influence of home-grown feeding program on pupils' enrolment before and after the commencement of the program.

3. determine the effect of home-grown feeding program on pupils' academic performance in the study area.

4. identify are the challenges of the Home Grown School Feeding Programme in the study area.

\section{Methodology}

Research Design

A descriptive research design was used for this study. 


\section{Setting of Study}

This study took place in 4 purposively selected LGAs in Abeokuta metropolis in Ogun State, Southwest Nigeria. Study Population

The population comprised of public teachers and primary school pupils who are in $1-3$ in the selected schools practicing HGFSP in the study area.

\section{Sampling and Sampling Technique}

The sample size comprises of seven hundred and eighty (780) public primary schools in Abeokuta metropolis. A multistage sampling technique was used. This procedure involved first dividing the study area into zones and Egba zone was selected for the study comprises of Abeokuta North, Abeokuta South Owode-Obafemi and Odeda Local Government Areas. Secondly, purposive sampling was used to select the public primary schools in all the four (4) Local Government where the HGFSP was carried out.Thirdly involves the selection of schools in different LGAs and lastly, nine (9) public primary schools' pupils (i.e in primary 1, 2, and 3 respectively) were randomly selected for the study. The total sample size for the study was seven hundred and eighty (780) primary schools' student and seventy (70) teachers.

\section{Instruments for Data Collection}

A self-administered questionnaire was used to obtain information about Home Grown School Feeding Programme from pupils and teachers. It consists of section A, B, C, and D. The face validity of the instrument was validated by two other experts and the reliability established from the result of two schools in Ogun State that is not included in the study area. Ahigh-reliability co-efficient of 0.902 was obtained hence, the instrument was considered reliable for use in this study.

\section{Method of Data Collection}

The researchers had meeting with the school head teachers who were used as research assistants. The procedure fordata collection was explained and their consent obtained. The teachers explained the content of the questionnaire to the pupils. Data was retrieved from each school on agreed dates by the researchers. A total of eight hundred and fifty (850) was distributed and seven hundred and eighty (780) was retrieved making a total of $91.8 \%$ responses rate.

\section{Method of Data Analysis}

Data generated were analyzed using SPSS Version 21. Descriptive statistics such as frequency count, percentages mean and standard deviation were used for the study.

Inclusion criteria

Schools currently providing school meals (In-school) for the past six months.

Exclusion criteria

Schools not currently providing school meals (In-school).

\section{Ethical Consideration}

Ethical review and approval was obtained from the Ethical Committee of the State Ministries of Education and Health.

\section{Result of the findings \\ Socio-Demographic Characteristics of Respondents}

A total of seven hundred and eighty (780) pupils completed the questionnaire, result in Table 1 reveals that above half $(51.3 \%)$ of the pupils were males, and $(48.7 \%)$ were females. The age of the respondents was ranged between 4 to above 10 years. distribution about the age of the pupils was as follows: $(43.6 \%)$ were between the age $4-$ 6years, $33.3 \%$ were 7 - 9years, and $23.1 \%$ were above 10years with the mean age of $6.32+0.35$ SD. Based on classes, $39.5 \%$ were in primary $2,32.9 \%$ were in primary 1 and $27.6 \%$ were in primary 3 . On the study location, above half (56.4\%) of the pupils were living in the urban area while $43.6 \%$ were in the rural area as at the time of this study.There are more pupils in urban than rural area. Result in Table 2 shows the mean anthropometric characteristics of the children. The result showed that the pupils had a mean height of $129.72 \pm 11.43$, weight of $24.32 \pm 5.41$, weight for age of $1.76 \pm 1.83$, height for age of $2.93 \pm 2.84$ and BMI for age of $0.074 \pm 1.25$. The anthropometric status of the pupilsreveals that majority $(94.9 \%)$ has normal weight-for-age, $4.5 \%$ were underweight and $0.6 \%$ has severe underweight, while majority $(96.2 \%)$ of the pupils also has normal height-for age, $3.2 \%$ were stunted and $0.6 \%$ has severe stunting. However, majority $(94.0 \%)$ of the respondents has normal BMI-for-age while severe wasting, wasting, overweight and obesity observed in this study was $0.6 \%, 1.5 \%, 2.6 \%$, and $1.3 \%$ respectively. 
Table 1: Background information of the pupils sampled. $(n=780)$.

\begin{tabular}{|l|l|l|}
\hline Variables & Frequency & Percentages (\%) \\
\hline Sex & & \\
\hline Male & 400 & 51.3 \\
\hline Female & 380 & 48.7 \\
\hline Age in years & & \\
\hline $4-6$ & 340 & 43.6 \\
\hline $7-9$ & 260 & 33,3 \\
\hline Above 10 & 180 & 23.1 \\
\hline Class of the pupils & & \\
\hline Primary 1 & 250 & 32.1 \\
\hline Primary 2 & 300 & 38.5 \\
\hline Primary 3 & 230 & 29.4 \\
\hline Location & & \\
\hline Rural & 340 & 43.6 \\
\hline Urban & 440 & 56.4 \\
\hline
\end{tabular}

Table 2: Food habit and Anthropometric characteristics of the pupils.

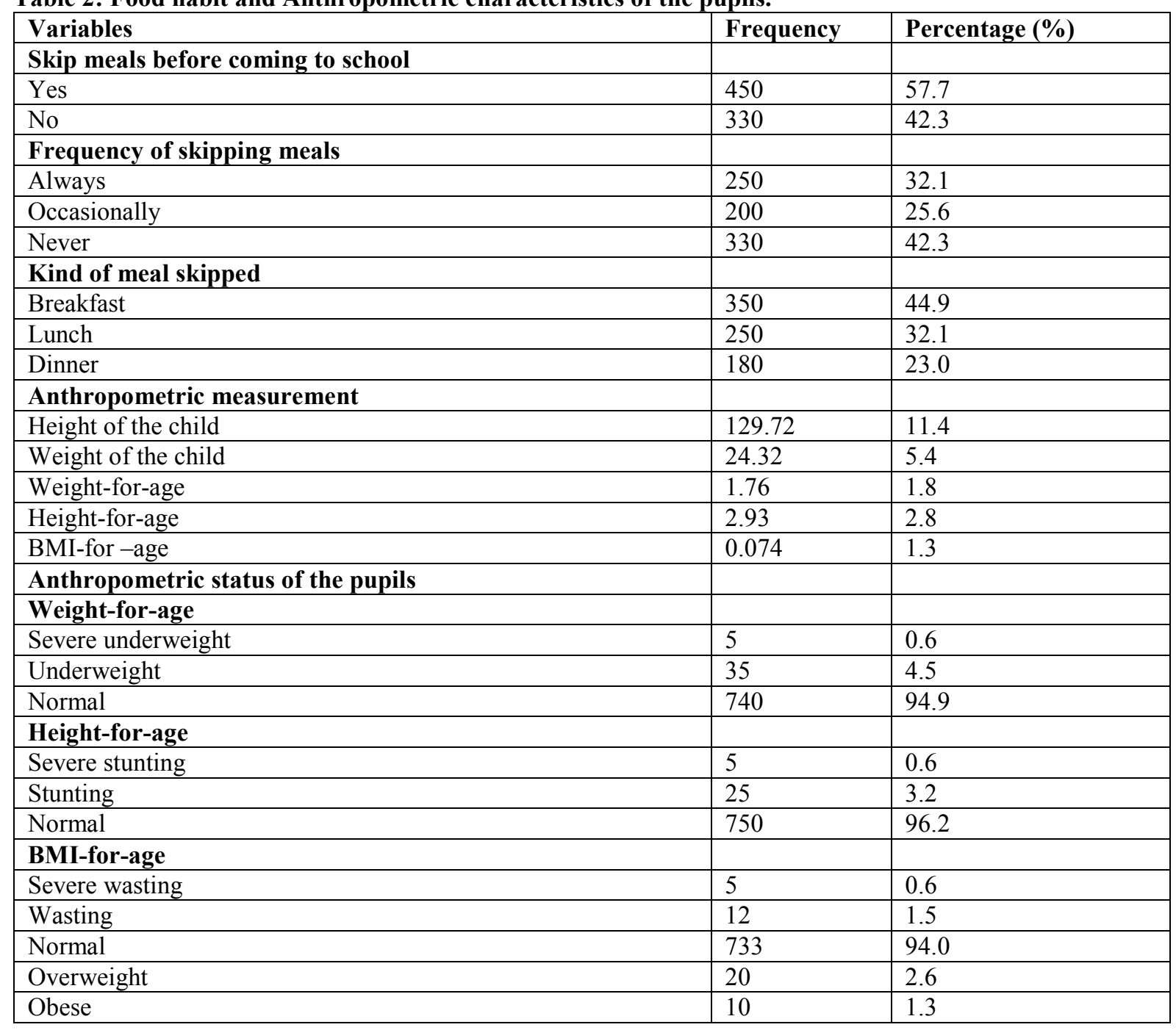

Section B: Influence of teachers on home-grown feeding program on pupils' enrolment before and after the commencement of the program.

Results in Table 3 reveal the influence of teachers on home grown school feeding programme. Finding shows that before the HGSFP majority (64.3\%) of the teachers indicated that the meals served are assorted and nutritious such as yam, cocoyam porridge, rice, beans, yam porridge, bread, vegetables, eggs, beef, fruits, chicken, egusi garnished 
with vegetables are rich, while above half $(56.1 \%)$ of the teachers reveal that SFP have great effect on pupil's cognitive development, $50.0 \%$ of the respondents reveal that there is policy guideline to ensure the sustainability of the school feeding programme. After the implementation of home grown school feeding programme, finding shows that all $(100.0 \%)$ of the teacher indicated that the meals served are assorted and nutritious such as yam, cocoyam porridge, rice, beans, yam porridge, bread, vegetables, eggs, beef, fruits, chicken, egusi garnished with vegetables are rich, the menu giving to pupils are based on the state government's guidelines to accommodate seasonal needs and local availability while majority $(92.9 \%)$ of the teacher indicated that there is an increase in school enrolment due to the provision of HGSFP, $85.7 \%$ of them reveals that the HGSFP is funded through cost sharing between the state and local governments, and further $82.9 \%$ of the respondents reveal that SFP have great effect on pupil's cognitive development. Furthermore, $78.6 \%$ of the respondents reveal that there is policy guideline to ensure the sustainability of the school feeding programme. This is very important, not only to ensure sustainability, but also uniformity in programme implementation in terms of the content (menu) of food served to pupils, timing for school meals, hygiene, food preparation, environment and so on., and $77.1 \%$ of them reveals that SFP program attracts pupils to come to school, most especially the poor community and improve their (children) performance. This is an indication that the school feeding was initially a federal government programme but was implemented in the State under the cover of Home Grown School Feeding and Health Programme with appropriate funding support. The initiative of the government has however been re-packaged and modified to currently being funded by the state and local governments through cost sharing. This is evident from the results on the table as $85.7 \%$ of the respondents indicated that the programme is funded through cost-sharing between the state and local governments.

Table 3: Influence of teachers on home-grown feeding program on pupils' enrolment before and after the commencement of the program.

\begin{tabular}{|l|l|l|l|l|}
\hline Influence of HGSFP & Before & & After & \\
\hline $\begin{array}{l}\text { Meals are provided for the pupils daily and promptly while in } \\
\text { school. }\end{array}$ & Yes (\%) & No (\%) & Yes(\%) & No (\%) \\
\hline $\begin{array}{l}\text { The government formulates the policy objectives and monitors } \\
\text { the implementation of the school feeding programme. }\end{array}$ & $30(43.9)$ & $40(78.6)$ & $40(56.1)$ & $30(43.9)$ \\
\hline $\begin{array}{l}\text { The HGSFP is funded through cost sharing between the state and } \\
\text { local governments. }\end{array}$ & $25(35.7)$ & $45(64.3)$ & $60(85.7)$ & $10(14.3)$ \\
\hline $\begin{array}{l}\text { There is policy guideline to ensure the sustainability of the } \\
\text { school feeding programme. }\end{array}$ & $\begin{array}{l}35 \\
(50.0)\end{array}$ & $35(50.0)$ & $55(78.6)$ & $15(21.4)$ \\
\hline The programme enjoys support from international organizations. & $10(14.3)$ & $60(85.7)$ & $10(14.3)$ & $60(85.7)$ \\
\hline $\begin{array}{l}\text { The meals served are assorted and nutritious such as yam, } \\
\text { cocoyam porridge, rice, beans, yam porridge, bread, vegetables, } \\
\text { eggs, beef, fruits, chicken, egusi garnished with vegetables are } \\
\text { rich. }\end{array}$ & $45(64.3)$ & $25(35.7)$ & $70(100.0)$ & $0(0.0)$ \\
\hline $\begin{array}{l}\text { There is an increase in school enrolment due to the provision of } \\
\text { HGSFP in the area. }\end{array}$ & $16(22.9)$ & $54(77.1)$ & $65(92.9)$ & $5(7.1)$ \\
\hline $\begin{array}{l}\text { SFP program attracts pupils to come to school, most especially } \\
\text { the poor community and improve their (children) performance. }\end{array}$ & $20(28.6)$ & $50(71.4)$ & $54(77.1)$ & $16(22.9)$ \\
\hline SFP ensure smooth and effective classroom management. & $28(40.0)$ & $42(60.0)$ & $45(64.3)$ & $25(35.7)$ \\
\hline SFP have great effect on pupil's cognitive development. & $40(56.1)$ & $30(43.9)$ & $58(82.9)$ & $12(17.1)$ \\
\hline
\end{tabular}

Effect of home-grown feeding program on pupils' academic performance in the study area.

Table 3 presents the respondents' opinions on the effects of home grown school feeding programme on pupils' academic performance. The Table shows that majority $(84.3 \%)$ of the respondents strongly agreed and $15.7 \%$ agreed that school feeding program stimulate local food production and boost income of family members ranked 1 st with a mean score of 3.84 . In the same vein $82.9 \%$ of the respondents also strongly agrees and $17.1 \%$ agreed that due to home grown school feeding programmme, the retention rate in school is quite high and impressive; this ranked $2^{\text {nd }}$ with a mean score of 3.83 . Result on the table further shows that $80.0 \%$ and $14.3 \%$ of the respondents strongly agreed and agreed that drop-out rate of pupils have increased since the introduction of the home grown school feeding programme and ranked $3^{\text {rd }}$ with a mean score of 3.74 . Furthermore, $71.4 \%$ of the respondent strongly agreed and $28.6 \%$ agreed that pupils' academic performance in end of term and session exams has been improved upon and ranked $4^{\text {th }}$ with the mean value of 3.71 . Also, $70.0 \%$ of the respondent strongly agreed and $30.0 \%$ agreed that school feeding program provide ready-made markets for agricultural produceand ranked $5^{\text {th }}$ with the mean value of 3.70 . Majority $(77.1 \%)$ of the respondent strongly agreed and $17.1 \%$ agreed that home grown school feeding programme plays a great deal of retaining pupils in your school and ranked $6^{\text {th }}$ with the mean 
value of 3.66 in the study area.It is however important to know that the effect of home grown school feeding programme cannot be the same on pupils across the selected schools in the state in absolute terms and this explains why the pupils' performance in central examinations varies from one school to the other. The result also revealed that majority of the respondents agreed that school feeding program influence child growth and development and has powerful influence on the child's learning process in the area of physical, social, emotional and cognitive development.

Table 4: Effect of HGSFP on pupils' academic performance (teacher).

\begin{tabular}{|c|c|c|c|c|c|c|}
\hline $\begin{array}{l}\text { Effect of HGSFP on pupils academic } \\
\text { performance (teacher) }\end{array}$ & SA(\%) & $\mathbf{A}(\%)$ & $D(\%)$ & $\operatorname{SD}(\%)$ & Mean & Ranked \\
\hline $\begin{array}{l}\text { There is improvement in pupils' performance } \\
\text { in both curricular and extra-curricular activities } \\
\text { in the school }\end{array}$ & $41(58.6)$ & $18(25.7)$ & $7(10.0)$ & $4(5.7)$ & 3.37 & $9^{\text {th }}$ \\
\hline $\begin{array}{l}\text { Pupils' academic performance in end of term } \\
\text { and session exams has been improved upon. }\end{array}$ & $50(71.4)$ & $20(28.6)$ & $0(0.0)$ & $0(0.0)$ & 3.71 & $4^{\text {th }}$ \\
\hline $\begin{array}{l}\text { Pupils' academics performance in class tests } \\
\text { was improved upon. }\end{array}$ & $48(68.6)$ & $18(25.7)$ & $4(5.7)$ & $0(0.0)$ & 3.63 & $7^{\text {th }}$ \\
\hline $\begin{array}{l}\text { Pupils' performance in class tests/exams have } \\
\text { nothing to do with school feeding served a } \\
\text { times. }\end{array}$ & $49(70.0)$ & $14(20.0)$ & $0(0.0)$ & $7(10.0)$ & 3.50 & $8^{\text {th }}$ \\
\hline $\begin{array}{l}\text { School feeding program stimulate local food } \\
\text { production and boost income of Family } \\
\text { members. }\end{array}$ & $59(84.3)$ & $11(15.7)$ & $0(0.0)$ & $0(0.0)$ & 3.84 & $1^{\text {st }}$ \\
\hline $\begin{array}{l}\text { Food vendors are fully integrated in the } \\
\text { program through which local farmers provide } \\
\text { them with the necessary local materials for the } \\
\text { meals. }\end{array}$ & $39(55.7)$ & $10(14.3)$ & $2(2.9)$ & $19(27.1)$ & 2.99 & $10^{\text {th }}$ \\
\hline $\begin{array}{l}\text { School feeding program provide ready-made } \\
\text { markets for agricultural produce. }\end{array}$ & $49(70.0)$ & $21(30.0)$ & $0(0.0)$ & $0(0.0)$ & 3.70 & $5^{\text {th }}$ \\
\hline $\begin{array}{l}\text { Home Grown School Feeding Programme } \\
\text { plays a great deal of retaining pupils in your } \\
\text { school }\end{array}$ & $54(77.1)$ & $12(17.1)$ & $0(0.0)$ & $4(5.7)$ & 3.66 & $6^{\text {th }}$ \\
\hline $\begin{array}{l}\text { Drop-out rate of pupils have increased since the } \\
\text { introduction of the Home Grown School } \\
\text { Feeding Programme. }\end{array}$ & $56(80.0)$ & $10(14.3)$ & $4(5.7)$ & $0(0.0)$ & 3.74 & $3^{\text {rd }}$ \\
\hline $\begin{array}{l}\text { Due to home Grown School Feeding } \\
\text { Programmme, the retention rate in school is } \\
\text { quite high and impressive. }\end{array}$ & $58(82.9)$ & $12(17.1)$ & $0(0.0)$ & $0(0.0)$ & 3.83 & $2^{\text {nd }}$ \\
\hline
\end{tabular}

Challenges of the Home Grown School Feeding Programme among the pupils in the study area.

Result in Table 5 reveals the challenges of the home grown school feeding programme among the pupils in the study area. Findings shows that majority $(95.7 \%)$ of the respondent indicates overcrowded classroom in the study area. The recommended rate by UNESCO standard of teacher-pupil ratio of 1-40 in elementary schools is a challenge in most of the public primary school in the study area.Majority $(91.4 \%)$ of the respondents reveals inadequate storage facility. Lack of adequate facility to store food items and ingredient collected or purchase by the vendor create setback or spoil and inturn affect the quality of the food served. Majority ( $88.6 \%)$ of them reveals lack of effective monitoring and evaluation system and major challenges of HGSFP among the pupils in the study area. Some of the respondents however, stated that there exists some form of monitoring systems at the state, local and school levels. At the state level, the state monitoring officers and state steering committee responsible for programme oversight, the state ministry of education and the state universal basic education board are responsible for collecting data on school enrolment and attendance on regular basis; the ministry of health is responsible for collecting data on child health and nutritional status; Local government education authority secretaries and planning officers are responsible for collecting weekly feeding forms that consist of the number of pupils that have been fed and for collating the data for the programme and the zonal inspectors of education are responsible for monitoring the feeding process, environmental health and enrolment data. At the school level, the school-based monitoring committees are responsible for the programme oversight; the quality of the food is monitored by the head teacher or health teacher. Others challenges were insufficient funding $85.7 \%, 80.0 \%$ regular hike in food prices, $71.4 \%$ seasonality and $68.6 \%$ of pupils have no access to good source of water after meals as challenges of the HGSFP among the respondents. This implies lack of fund in execute some plan were not adequate or not 
releases in time to implement the work has at when due, lack of insufficient fund and failure to release fund at the right time leads to regular hike in most of the food items in most market. Seasonality of food items are also challenges facing the home grown school feeding programme in the study area.

Table 5: Challenges of HGSFP

\begin{tabular}{|l|l|l|}
\hline Challenges of HGSFP & Yes (\%) & No (\%) \\
\hline Regular hike in food prices & $56(80.0)$ & $14(20.0)$ \\
\hline Inadequate storage facility & $64(91.4)$ & $6(8.6)$ \\
\hline Inadequate supply of food stuffs & $43(61.4)$ & $27(38.6)$ \\
\hline Seasonality & $50(71.4)$ & $20(28.6)$ \\
\hline Insufficient funding & $60(85.7)$ & $10(14.3)$ \\
\hline Overcrowded classrooms & $66(94.3)$ & $4(5.7)$ \\
\hline Lack of effective monitoring and evaluation system & $62(88.6)$ & $8(11.4)$ \\
\hline Absence of legal frame work and policy to support the HGSFP & $35(50.0)$ & $35(50.0)$ \\
\hline Insufficient classrooms and furniture to cope with increased enrolment & $45(64.3)$ & $25(35.7)$ \\
\hline Pupils have no access to good source of water after meals & $48(68.6)$ & $22(31.4)$ \\
\hline
\end{tabular}

\section{Discussion of Findings}

The home grown school feeding program is a social wellbeing and security web that is meant to support many vulnerable children and pupils in developing countries in order to develop and attract them back to school for learning activities. Evidence has shown that when school meal is served pupils while in school, it increases enrolment of others, attendance and leads to retention of programme. There is also the view that a school feeding programme improves the academic performance of pupils as well as reducing the dropout rate among beneficiaries in the study area. This finding was supported by Ngussa and Twarira (2020) who reported that pupils viewed food served as enough and delicious. In contrast, Yendaw and Dayour, (2015); and Mensah (2016) reported that pupils viewed meals prepared for them were not served on time, moderately low quality, and not sufficient. The school feeding can be in turn grouped into two common categories: programme that provides meals and programme that provides high-energy biscuits or snacks to generate greater impacts on school enrolment, retention rates, and reduce gender or social gaps (Akanbi, 2013). In view of this, Oyeniran (2014) noted that the effect of school feeding on performance also depends on other factors such as adequate learning materials, physical facilities and teacher motivation, to mention a few. This is similar to the findings of the World Food Programme (2010); Aurino, Tranchant, Diallo, and Gelli (2018); Bundy et al. (2018); Maijo (2019); Snilstveit et al. (2015); Mwendwa, and Gori (2019); Azubuike and Mbah, (2019); and Kilu and Mugambi (2019) who reported levels of increase in enrolment and attendance, retention promote retention, reducing absenteeism and dropouts, and improving learning outcomes among primary schools' pupils. This finding is also in agreement with the work of (Uduku, 2011) who reported that nutritional and health status is powerful influences on a child's learning and how a child performs in school. Children who lack certain nutrients in their food diet do not have the same potential for learning as healthy and well-nourished children. Children with cognitive and sensory impairments naturally perform less and are more likely to repeat grades. The study also showed that pupils were served with local foods such as yam, rice, bean porridge, etc. this is in line with Devereux, Hochfeld, Karriem, Mensah, Morahanye, Msimango, Mukubonda, Naicker, Nkomo, Sanders, Sanousi, (2018) and Sitao, (2018) who reported that most products used were grown locally and will improve the income of farmers in the areas. However, even though pupils perceived food as being delicious, the food served pupils were not balanced as the majority reported they were not given eggs, meat, fish, and fruits. In other words, the school food menu needs to incorporate appropriate and balance meals for school children. Zobo drink, buns, biscuits chin-chin, and noodles were not supposed to be given to the children as they were not in the meal plan of the Nigeria School Feeding Programme. As observed by Oyefade (2014), several factors with significant impact on many dimensions of poverty on school attendance and education quality, particularly early childhood malnutrition, deprivation based on gender and income inequality tend to be responsible. According to Yunusa (2012) noted that students in school feeding programmes have the potential for improving their performance because it enabled them attend school regularly and studied more effectively. Despite the positive impact of SFP, there have been some shortcomings on its implementation. For instance, policy makers and donors argue that these programmes are a costly approach to producing the stated education and nutrition goals and those other more economical procedures exist (Adelman, et al., 2008). Another general setback of SFP is that it usually fails in implementation due to unpredictable food availability or unorganized meals that interrupt academic activity (Adelman, et al., 2008).

\section{Conclusion and Recommendation Conclusion}

Conclusively, the perceived effect of HGSFP was a very good initiative by the government as it enhances pupils 
enrollment, attendance, retention dropout, class participation, quality, and cognitive development. Food served was locally procured by vendors within the study area. The study revealed a moderate level of perceived effectiveness of the home grown school feeding program in Ogun State. Meal skipping was prevalent as many of the children skipped meals while breakfast was the meal skipped by many of those who skipped meals. A vast majority of the children studied were normal while various forms of malnutrition were also present. Also, they were served locally grown food. The study also concluded that the state government should double its efforts to address the challenges identified in the programme implementation in order to sustain the impressive pupils' enrolment and academic performance. Unfortunately, this study found that the implementation of the Home Grown School Feeding Programme falls short of some of the standards stipulated by the World Food Programme due to various challenges. Their age, sex, and class level was not significant with their perceived effect of HGSFP while location was significant.

\section{Recommendation}

The following was recommendations were by for the study as follows:

1. Government's urgent investment in school farms as this in turn will not only boost agriculture but can also enhance learning by inculcating the rudiments of agriculture in school.

2. Ministry of education and the State should review the home grown school feeding program, make it continuous and extend it in schools in poverty ridden areas.

3. Ministry of education should mandate the vendors to buy food stuffs such as rice, beans, meat, egg, fish, and vegetables directly from local farmers in other to boost crop production.

4. During the modification of home grown school feeding program, it is important to include local producers and schools in the decision making process on the type of food needed.

5. Government should build a reliable framework that focus on how home grown school feeding program can effectively contribute to improving educational outcomes and meeting the nutrition and health needs of school age children.

6. The teachers and the school management to ensure pupils attend school as expected, by ensuring all the pupils benefit maximally from the provision of food in school.

\section{References}

Adelman, S., D. Gilligan and K. Lehrer. (2008). How effective are food for education programs?: A critical assessment of the evidence from developing countries. International Food Policy Research Institute.

Ahmed, A. U. (2004). Impact of Feeding Children in School: Evidence from Bangladesh. The United Nations University International Food Policy Research Institute, Washington, D.C.

Akanbi, G.O. (2013). Home Grown School Feeding and Health Programme in Nigeria: An Innovative Approach to Boosting Enrolment in Public Primary Schools - A Study of Osun State, 2002-2010. African Symposium, 11(2), 8-12.

Aliyar, R., Gelli, A., and Hamdani, S. H. (2015). A Review of Nutritional Guidelines and Menu Compositions for School Feeding Programs in 12 Countries. Frontiers in public health, 3, 148. https://doi.org/10.3389/fpubh.2015.00148.

Aurino, E., Tranchant, J P., Diallo, A. S., and Gelli, A. (2018). School Feeding or General Food Distribution? Quasi-Experimental Evidence on the Educational Impacts of Emergency Food Assistance during Conflict in Mali. UNICEF Office of Research Innocenti Working Paper WP-2018-04 | June 2018.

Azubuike, O. C., and Mbah, P. E. (2019). Challenges of Child Nutrition: An Analysis of School Feeding Programmes (SFP) in South Eastern Nigeria. Savanna Journal of Basic and Applied Sciences, 1(1), 104-110. Retrieved from http://www.sjbas.com.ng.

Bashir, S., Lockheed, M., Ninan, E., and Tan, J. P. (2018). Facing Forward: Schooling for Learning in Africa (pp. 127-133). Washington, DC: AFD and World Bank. Retrieved from https://openknowledge.worldbank.org/handle/10986/29377.

Bundy, D., Burbano, C., Grosh, M., Gelli, A. M., Jukes, C.H., and Drake, L.J. (2009). Rethinking School Feeding: Social Safety Nets, Child Development, and the Education Sector. The World Food Programme and the World Bank, Washington, DC. http://dx.doi.org/10.1596/978-0-8213-7974-5.

Cole, R. (2013). Community participation and Successful school feeding programmes in Southern Nigeria. UNIPRESS: Ibadan.

Devereux, S., Hochfeld, T., Karriem, A., Mensah, C., Morahanye, M., Msimango, T., Mukubonda, A., Naicker, S., Nkomo, G., Sanders, D., and Sanousi, M. (2018). "School Feeding in South Africa: What we know, what we don't know, what we need to know, what we need to do" Food Security SA Working Paper Series No. 004. DST-NRF Centre of Excellence in Food Security, South Africa.

Gelli, A., Masset, E., Folson, G., Kusi, A and Arhinful, D.K (2016). "Evaluation of Alternative School Feeding Models on Nutrition, Education, Agriculture and Other Social 
Outcomes in Gombe: Rationale, Randomized Design and Baseline Data.” Trials 17 (37).

Lawson, T. (2012). Impact of School Feeding Programs on Educational, Nutritional, and Agricultural Development Goals: A Systematic Review of Literature. Retrieved from https://ideas.repec.org/p/ags/midagr/142466.html.

Maijo, S. N. (2019). Impact of School Feeding Programme on Learners' Academic Performance in Mlunduzi Ward, Tanzania. International Journal of Educational Studies, 5(2), 111-114. https://doi.org/10.33687/educ.005.03.2667.

Mensah, A. O. (2016). Contract Management, Monitoring and Evaluation of Ghana School Feeding Programme at AtwimaKwanwoma District. International Journal of Scientific and Technology Research, 5, 268-278.

Mohamed, A. (2015). Influence of feeding programs on the participation of learners at early childhood development education institutions: A case of Bungoma South district. International Academic Journal of Social Sciences and Education, 1 (4), 1-14.

Mwendwa, E. M., and Gori, J. M. (2019). Relationship Between School Feeding Programmes and the Pupils' School Attentance in Public Primary Schools in Kitui County, Kenya. International journal for innovation,education and research, 7(10), 1-14. https://doi.org/10.31686/ijier.Vol7.Iss10.1669.

Ngussa, B. M., and Twarira, J. H. (2020). Correlation between Food Provision, Teachers' Involvement and Pupils' Engagement in Learning: A Case of Primary Schools in Arusha City, Tanzania. East African Journal of Education and Social Sciences, 1(1), 1-11. http://dx.doi.org/10.46606/eajess2020v01i01.0001.

Nyarko, S.H. (2014). Assessment of the school feeding programme in Ghana: A study of primary schools in the Abura-Asebu-Kwamankese district in the Central region of Ghana. International Journal of Research in Social Sciences, 4 (2), 1-15.

Oyefade, S.A. (2014). Administration of Home Grown School Feeding and Health Programme in Osun State. Unpublished MPA Long essay, Department of Public Administration, Faculty of Administration, Obafemi Awolowo University, Ile-Ife.

Oyeniran, O. B. (2014). Rich Country Poor People: Nigeria's Poverty in the Midst of Plenty. Manchester, U.K: Technopol Publishers.

Sitao, V. J. R. (2018). An assessment of school feeding programme - pilot phase and its relationship with enrolment, attendance, retention and the local agricultural production in Nampula province in Mozambique. Submitted in fulfilment of the requirement for the degree Doctor of Philosophiae in Public Health Supervisor: Professor Josephine Kiamba, Co-supervisor: Professor Cheryl M E McCrindle. School of Health Systems and Public Health Faculty of Health Sciences University of Pretoria July 2018 (Unpublished PhD dissertation,S28279825).

Snilstveit, B., Stevenson J., Phillips D., Vojtkova, M., and Gallagher E. (2015). Interventions for Improving Learning Outcomes and Access to Education in Low and Middle-Income Countries: A Systematic Review." 3ie Systematic Review, 24. London: International Initiative for Impact Evaluation (3ie).

Uduku. F. (2011). School Building Design for Feeding Programme and Community Outreach: Insights from Ghana and South Africa. International Journal of Educational Development, 31, 59-66. http://dx.doi.org/10.1016/j.ijedudev.2010.06.005.

World Food Programme, (2015). School meals and Education. Accessed from documents. wfp.org/stellent/groups/public/.

World Food Programme. (2010). School meals. Available at http://www.wfp.org/schools.meals.

Yendaw, E., and Dayour, F. (2015). Effect of the National School Feeding Programme on Pupils' Enrolment, Attendance and Retention: A Case Study of Nyoglo of the Savelugu-Nantong Municipality, Ghana. British Journal of Education, Society and Behavioural Science, 5(3), 341-353. doi: 10.9734/bjesbs/2015/14271.

Yunusa, I., Gumel, A. M. Adegbusi, K. and Adegbusi. S. (2012). School feeding program in Nigeria: A vehicle for nourishment of pupils. The African Journal, 12: 53-67. 